Euskal ikerketen aldizkaria | Revue d'études basques |

Revista de estudios vascos | Basque studies review

$20 \mid 2017$

Numéro $X X$

\title{
Arnaud Oihenart prezeptista: lekukotasun baten oinarriak
}

Ana Toledo Lezeta

\section{OpenEdition}

Journals

Édition électronique

URL : https://journals.openedition.org/lapurdum/3605

DOI : 10.4000/lapurdum.3605

ISSN : 1965-0655

Éditeur

IKER

Édition imprimée

Date de publication : 1 janvier 2017

Pagination : 291-301

ISBN : 978-2-95534-135-3

ISSN : $1273-3830$

Référence électronique

Ana Toledo Lezeta, «Arnaud Oihenart prezeptista: lekukotasun baten oinarriak», Lapurdum [Linean], 20 2017, Sarean emana---an 01 janvier 2021, kontsultatu 17 septembre 2021. URL: http:// journals.openedition.org/lapurdum/3605 ; DOI: https://doi.org/10.4000/lapurdum.3605 


\title{
Arnaud Oihenart prezeptista: lekukotasun baten oinarriak
}

\author{
Ana M. TOLEDO LEZETA \\ Deustuko Unibertsitatea. Euskaltzaindia
}

Gauza jakina da Aita Lafittek 1967an argitaratu zuela Gure Herria aldizkarian Oihenarten paperen artean aurkitu zuen "Lart poétique basque, indiquee dans une lettre escritte a un cure du pays de Labourt au moys de mai de 1665".

Oihenartek aitortzen duenez, Lapurdiko apaiz batek helarazitako eskaerari erantzuna da. Antza denez, Lapurdiko apaiz horrek galdetu dio ea zein metodo jarraitu duen jadanik plazaratuak dituen poesiak mamitzeko eta ihardespen-gutunak apaiz lapurtarraren jakin-mina asetzea du xede. Jasotako gonbita onartu eta, lantegiari ekin zion Oihenartek.

Bistakoa da gutuna ez zuela bidali, Oihenarten paperen artean agertu baita eta ez izen-abizenez izendatzera iristen ez den lapurtar elizgizonen baten agirien artean. Ustezko erantzun-gutun hau arte poetikoa egituratzeko aitzakia hutsa izan zuen (Lasagabaster 2003: 182). Argiago esanda, ez zen egon abade lapurtarrik horrelako itaunik egin zionik: Oihenartek genero epistolarrera jo zuen argitaratuak zituen poesien euskarri teorikoak erakusteko. Gutunari sinesgarritasuna emateko norbaiti zuzendu behar zion. Horiek horrela, Lapurdiko apaiza Oihenarten irudimenak sortutako hartzailea baino ez da. Gutunak, genero bezala, jada ondo ezarrita zeukan forma eta egokia zen erudizio-gaiak erabiltzeko, ordurako bikain frogatuta zuenez. Bakarra aipatzeagatik, Horazioren Epistola ad Pisones, kasu.

Lerro hauetan zehar garatuko den azterketak bi helburu ditu; bata, arte poetikoan itxuratuz doan Lapurdiko apaizaren erretratua zirriborratzea; bestea, moldiztegiratu ez zuen eskuizkribuari darion poesiaren ulerkuntza adieraztea eta ulerkuntza horrek zenbateraino islatzen duen garaiak gertaera literarioaz zuen ikuspegia behatzea. Gutunean -gehienbat hasieran- bigarren pertsonaren marka azaltzen da, hots, Lapurdiko apaiza ordezkatzen duen izenordea: "zu" horrentzat idatzi du eta horri egozten dizkion ezaugarriak arakatuko dira. Bigarrenik, hartzaile horren jakinean jarri gura dituen ezagueren oinarriak mugatuko dira garaikideek poesiaz zeukaten ikusmoldearekin dituen kidetasunak atzemateko. Dena den, elkarrekin harremanetan dauden helburuak dira; izan ere, arte poetikoan barrena eratuz doan irakurle inplizituaren bereizgarri da ikasia izatea eta euskaraz poesia jantzia sortzeko 
euskarriak eraikitzea bilatzen du Oihenartek.

Xede hauek betetzeko azterlan honetan baliatutako bideak eragin du erantzunik gabe geratu den galderarik. Beraz, Oihenart poeta eta prezeptistak misterioa lagun izaten segituko du.

\section{Hartzailea: Lapurdiko apaiza}

Gutunaren jasotzailea irudimenaren fruitu badu ere, ez du arbitrariotasun hutsez aukeratu. Lapurdiko apaiz batek itaundu omen dio nola taxutu zituen poesiak. Parisen 1657 an plazaratu zuen Oten gaztaroa neurtitzetan idazlan poetikoan frantses soilean irakurleari zuzendutako hitzaurrea honela bukatzen zuen:

J'ai fait ajouter à la fin quelques rimes pies, pour exciter ceux qui ont plus d'affection et d'aptitude que moi à la Poésie à en faire de meilleurs et en plus grand nombre. ( 301$)^{1}$

Amaieran, eredu gisa, deboziozko neurtitzak erantsi ditu bera baino iaioagoak liratekeenak jardun horretara bultzatzeko. Erlijioa interes gune duen laikoa barnera dezakeen arren, buruen-buruenik, poesiak erakartzen eta neurtitzak paratzen trebea den elizgizonarentzako deia dela dirudi.

Arte poetikoari heltzen dionerako hizkuntza bakarrean baino gehiagotan burutua zuen obran, batez ere obra nagusian, Notitia utriusque Vasconiae tum Ibericae tum Aquitanicae... (1638, 1656) izenburupean jendarteratutakoan, agertua zuen Oihenartek prestakuntza sakoneko eta erudizio zabaleko gizona zela. Arte poetikoak, gainditu ez zuen bere behinbehineko idazketan (Lafitte, 1967: 10) bertan, erudizioaren erakuskari izaten jarraitzen du. Oihenartek hizkuntza desberdinetan (latina, gaztelera, italiera, euskara, frantsesa) idatzi duten poeten poesiak jatorrizko hizkuntzan ezagutzen ditu eta, bere horretan gordetzen, poeta horiengandik jasotako neurtitzak. Erretorikako ikasketak ere eguneratuak ditu, bereziki honek elocutioaren ataletako batean arakatzen zituen ahoskera-mailako baliabideei dagokienak.

Arte poetikoa adituarentzat idatzita ez egonagatik, metrika orokorreko eta euskal metrikako ezaguerak dituenarentzat da (Lasagabaster, 2003: 184). Eleanitza eta garaiko praxi poetikoa arrotz ez duena izateaz gainera, metrikaren barrutian moldatzen dena izan behar du Lapurdiko apaizak. Hala eta guztiz, kontzeptuak banan-banan argitzen dituenez Oihenartek, gutuna ez da erretorikaren hiztegi berezitua ondo baino hobeto ezagutzen duela uste den norbaitentzat. Beharbada, didaktikaren alorreko gomendioei erantzuten ari da, baina, zeinahi dela ere portaera horren zergatia, baliatzen duen hiztegi berezitua hartzaileak mendera ez dezakeen irudia proiektatzen du. Euskaraz eman izan balu ulergarria ez ezik, premiazkoa ere bazuen jokabidea, frantsesa hobesteak ez zuen beharrezko egiten. Euskaraz behartua zegokeen hiztegi berezitu hori erabiltzen lehena izango zelako eta, horrenbestez, ordu arte inork euskaraz landu gabeko hiztegia izanik, hitz tekniko bakoitzari esleitutako esanahia

1. Oihenarten testu poetikoak eta hauen paratestua erreferentzietan jasotzen den ediziotik aipatu dira. Baita orrialde-zenbakiak ere, jakina. 
azaltzera derrigortua zegokeelako, frantsesarekin ez bezala.

Delako Lapurdiko apaiza euskalduna da, bestela, nekez beregana baitzitzakeen Oihenartek euskara hutsean eratutako poesiak. Baita poesia zalea ere, poesia horiek bederen irakurriak ditu eta. Apaiz euskaldunari frantsesez zuzentzean eta aipatutako hitz tekniko bakoitza zehaztean, ez du bakarrik salatzen une horietan euskara ez duela jotzen poetikaz aritzeko gauza den tresnatzat (Garcia Galiano, 1993: 149) edo, bera behintzat ez dela gai erronka horri aurre egiteko, baita gutunaren hartzailea ere ez duela begiesten erretorikaren alorreko kontzeptuen esanahiak buruz dakizkien subjektu moduan. Egozten dio jakintzarik; urrutiago joan gabe, bost hizkuntzetan moldatzeko ahalmena. Haatik, eleanitza den apaiza eta, egin duen galdera egiteko, poesiak erakartzen duena, hitz teknikoen definizioa gogoraraztea ondo letorkiokeen solaskidetzat dauka Oihenartek. Irakurle eleanitz eta poesia zale batentzat idatzitako gutuna da, irakurle ikasi batentzakoa, gutun-egilearen jarrera didaktikoak irakurketa errazten badio ere. Ikasketa-planetan erretorikak lekua zuenez, zentzuzkoa dirudi pentsatzea elizgizon zein laiko ikasi oro gogoan hartu zuela. Ikasiak izanagatik, erretorikaren eremua ahantzi samarrik zutenak barneratu nahiak berak galdegin zekiokeen kontzeptuak argituz joatea.

Zahartzaroan -ordurako 71 urte ditu- taxututako gutunean jorratutako gaia ez zuen zeharo berria. Notitiaren 1638ko lehen ediziotik 1656ko bigarren ediziora alde handihandirik ez egon arren, aldaketarik nabarmenenak XIV. kapituluak izan zituen, gramatikari eskainitakoak, hain zuzen ere. Hiru azpiatal berri sartu zituen. Hirugarrenak, "De syllabarum quantitate"k (Oihenart, 1656: 589-589 bis) "bertsugintzako silaba-neurketaz" dihardu (Oihartzabal, 1994: 29). Silaba-neurketaz jardutetik urte batera argitaratu zuen Oten gaztaroa neurtitzetan, bere idazlan poetikoa. Nahiz eta irakurleari frantses soilean luzatzen dion hitzaurrean maitasunezko poesiak gazte denboran paratu dituela aitortu eta, orain, gaztaroa ondo amaitua duenean plazaratzeko arrazoitzat ordu arteko euskal praxi poetikoaren akatsekin behingoz bukatzea dela gaineratu, poesiak zuzen osatzeko ereduak euskal poetari eskuratuz, bada zantzurik uste izateko, gazte-denboran gabe, deboziozkoak legez, iragan hurbilean bertan mamitu zituela: besteak beste, juxtu argitaratu aurretxoan aztertuak zituen gai foniko-erritmikoak Notitiarako (Toledo, 2008: 151-153). Agian, maitemindu baten kexu, laudorio eta ordain-eskeak hirurogei eta lau urteko gizonarenak baino gaztearenak izatea egokiago zatekeelako egotzi zizkion gaztaroari maitasunezkoak, zergatiko funtsezkoagorik ere izan zezakeen arren: aurrerago baietsiko denez, bi ondu aldi desberdintzeak lagun zekiokeen batzuen eta besteen artean ezarri nahi zituen mugarri sendoak gardenago irudikatzera.

Esanak esan, maitasunezko eta deboziozko neurtitzen jaiotza denbora-tarte handiago edo txikiagoak bereizten duela ere, eredu zuzenak erakustea du batzuk eta besteak ezagutarazteko zio. Maisu bezala aurkezten da.

Maisu legez kaleratzen ditu guztiak, maitasunezkoak, zein erlijiozkoak. Bi eredu sortzea hautatu du. Antza, maitasunezkoak ontzeko baliatutako eredua ez zekusan erlijiozkoetara hedagarri. Eredu bat erlijiozkoentzat eta, beste bat, profanoentzat.

Arte poetikoa ere maisu gisa planteatzen du. Lehen agiri hau frantsesa bitarteko darabilen euskal poesiari buruzko araubide moduan, prezeptiba moduan, gauzatu zen. Hiru mende luzetan zehar ezezaguna izan zelarik, euskal poesiaren garapenean eragiteko egokierarik gabe geratu zen. Dena dela, itxuraz, berebiziko ahaleginik ere ez zuen egin lehen agiriaren egile izatearen ohorea bereganatzearekin batera euskal poesiaren ibilbidean arrastoa uzteko, moldiztegiratzeak eskatuko ziokeen behin betiko idazketa bat eman ez zionean, nola 
eta ezinak ez zuen behartu egitekoa bertan behera lagatzera.

Lantegi zailegian sartu ote zenaren susmoak atzerarazi ote zuen? Oso jakintsua izan arren, euskal poesiaz diharduen lehen arte poetikoa jorratzearen eskakizunak ere ez ziren badaezpadakoak: zenbait hizkuntza menderatzeaz gain, hizkuntza horietan landutako poesiaren ezaguera sakona premiazkoa zuen, baita erretorikaren alorreko kontzeptu ugari kudeatzen jakitea ere... Dokumentazio zabala bilatzeko, gobernatzeko eta antolatzeko gaitasuna zuela frogatua zeukan Notitian, baina historialari bezala agertutako zorroztasunmaila berberarekin arte poetiko batek galdatutakoari erantzuteko gauza ikusten ote zuen bere burua?

Zer esanik ez, arte poetikoak behin-behineko idazketa gainditu ez izanaren zergatiak ez dira argitu eta, seguruenik, ezta inoiz argituko ere. Aurreko pasartean adierazitako zalantza eta galdera horien jatorria arte poetikoari leporatu zaizkion akatsetan dago, dela hamabosteko bertso-lerroa latindarrek ez zutela erabili baieztatu izanean (Altuna, 1981: 326), dela, Haritschelhar-en esanetan, poeta gaztelarren neurtitzetatik jasotako aipamenetan beti zehaztasunez ez jokatzean (Lafitte, 1967: 10), dela poeta gaztelarrengandik eredu gisa ekarritako neurtitzen irakurketa metrikoan egindako okerretan (Lasagabaster, 2003: 185186), dela Petrarca eta Ariostorengandik hartutako neurtitzetan hizkuntza eta metrika italiarraz erakusten duen ezaguera eskasegian (Lasagabaster, 2003: 186-187), eta, ziurrenik, larriena izan daitekeenean:

La renovación pretendida por Oihenart se queda de hecho en meras propuestas métricas que van además a contrapelo de la estructura prosódica de la lengua vasca. (Lasagabaster, 1886: 120-121)

Jadanik iragarri denez, lerro hauen xedea ez da Oihenarten prezeptibari darion zorroztasuna neurtzea. Hemen ez da arakatuko euskaraz neurtitz zuzenak ontzeko finkatu zituen arauak egokiak ziren ala ez edo, aurrera eraman zuen azterketa hutsik gabea den ala ez, ezta, Oihenart prezeptistak agindutakoa Oihenart poetak estu-estu betea zuen ala ez ere (Altuna, 1994: 169-170), baizik eta, gutunak itxuratzen duen irakurle inplizituaren irudia zein gizarte-mailetako hartzaile errealarekin parekatzen den behatzearekin batera, hartzaile horren jarduera poetikoa gobernatzeko eskainitako prezeptibaren euskarri teorikoak, garaiko testuinguruan kokatuz, azaltzea.

\section{Oinarriak}

Gaur aho batez onartzen da Aristotelesen Poetikaz gero, gertaera literarioari buruzko gogoetarekin amaitu eta haren alderdi arauemailetik elikatu zirela XVI- XVII- XVIII. mendeetako poetikak. Poetikok ofizio moduan ulertzen zuten poetaren zeregina. Ofizioak ikasi egiten dira. Ofizio bakoitzak bere teknikak ditu eta teknika horiek bereganatuz lortzen du ikasleak ikasgai duen ofizioa menderatzea. Erromantizismoak itzulikatuko du mendetan indarrean dirauen ikuspegi hori. Aldaketa berebizikoa da. Chateaubriand-ek 184lean bukatu zuen Memoires d'outre-tomben esaten duenean, "Le style, et il y en a de mille sortes, ne s'apprend pas; c'est le dont du ciel, c'est le talent" (1951: 410), oso bestelakoa den pentsamendua azaleratzen du: ez da ikasten, zeruaren dohaina da; beraz, jaiotzetikoa, berezkoa. Chateaubriand-ekin, ordea, Erromantizismoan gaude, ordu arteko poetiken zimenduekin hautsi zuen aldi literarioan. 
Oihenartentzat, bere garaikideentzat bezala, neurtitzak paratzen ikasi egiten da. Lehenik eta behin poetak ereduak bilatu behar ditu eta ereduok imitatu. Imitazioa da sorkuntza artistikoaren oinarri emankorra. Oro har, imitazioaren arauak zerikusi gehiago du formarekin edukiarekin baino. Hala gertatzen da Oihenarten poetikan ere: Etxepareren idazlana kritikatzeko unera murrizten du gaiaren aipamena. Zernahi gisaz, aurrerago gaineratuko denez, berez, Oihenartek ez du gaia bera desegokitzat jotzen: gaiari lotzen zaizkion testumailako, nahiz igorlearekin eta hartzailearekin harremanetan dauden zertzeladetara darama auzia.

Euskal poesia berritzea du jomuga. Gutunean zehar poetari ereduak jarraitzea eskatzeaz bestalde, erretorikak ahoskeraren planoan lekutzen zituen baliabideen erabilerara biltzen du arreta edo, J. Dubois eta Liejako taldeak adierazlearen mailan kokatzen dituzten metaplasmo deituriko figuretara. Oihenartek ezarritako arauek, neurtitzaren neurriez, lizentzia metrikoekin jokatzeko moduaz, arte nagusiko neurtitzaren etenaz, azentuaz, errimaz... dihardute. Ahoskeraren eta erritmoaren eremuko arauak dira zabalen jorratzen dituenak.

Euskaraz osatutako neurtitzak ez dira zuzenak. Horra hor, 1657an neurtitzak ezagutarazteko izan zuen zioa; orain, 1665ean, neurtitz horiek nola ondu zituen galdetu dion apaizari erantzutea du arte poetikoa idazteko arrazoi.

Iraganean neurtitz zuzenik gauzatu ez baldin bada, zertan huts egin zuten argitzea dagokio. Errazena eta bere buruari erramu bonetik bikainena ipintzeko aukerarik paregabeena lehenaldi osoaren gaitzespenak ematen zion. Urruti ibili ez arren, ez zen horrenbestera iritsi, aurretik ere neurtitz zuzenik eratu zela aitortu zuen neurrian: "Andre Emilia" dotorea da. Nafarroa Garaian eta Bizkaian ere bada kantarik "Andre Emilia"k baliatutako neurriarekin bat datorrenik. Baita metodo ona segitu duen egile bakar bat ere: Aita Haranburu, nahiz eta metodo on horretan ez oinarritu bere bertso oro. Honela bada, Oihenartek bereak plazaratu aitzin, euskaraz neurtitz zuzen bakan batzuk egin direnez, izendatzen dituen ereduak ez dira gaztelaniaren, italieraren edo latinaren barrutikoak soilik. Ezagutzen den lehen poetika berea izanik, aurrea hartzen dioten euskal neurtitz zuzenak zeren fruitu ote dira? Euskal poesiak betekizun zituen arauak ezagutu gabe, zuzen jarduten asmatu zuten. Zorte-kolpearen ala kultura poetikoren baten jabe izatearen emaitza ote dira? Edo berritzailea izanagatik, ordu arte ehotako tradizioaren sustrai guztiekin eten gabe, ezarri nahi zuen berrikuntza errotzea ahalbidetzen zion sustrairen bat aurkitu ote zuen?

Bidenabar esanda, harrigarri samarra suertatzen da, euskaraz neurtitz zuzenak taxutu zituztenen artean, arte poetikoa baino lehenago mamitu zuen hamalaurkun bakarrean goraipatu zuen Zalgize poetaren arrastorik ez uztea: ez izenik, ez honengandik bildutako neurtitz bakar baten aipamenik ere. Hamalaurkunean laudatzen badu, neurtitz zuzenak moldatuko zituen, ez? Zergatik ez ote zion laginen bati toki egin?

Zalgizeren omenetan burutu zuen hamalaurkuna arte poetikoa idatzi aurrekoa da. 1657an Parisen moldiztegiratutako poesien artean ez dago, baina, agidanez, poesien beste argitalpen bat ere bideratu zuen Oihenartek. Jusef Egiategik 1785ean zioenez, "ta azkenekoz Zaharzaroa ere neurthitzetan eman, Pauen moldizkidatia 1664 urthian" (28)². Paueko

2. Aipamena eta orrialdea erreferentzietan jasotako ediziokoak dira. 
ediziokoa edo izan daitekeen Baionako herri-liburutegian gordetako alean jasotzen den "Zalgiz iaun Paueko Korte gehienean Erregeren kontseilari zenaren gorazarretan" ondutako hamalaurkunean dioenez,

Halakotz hik, Zalgiz, Euskaldun Poeta, / Burura behar duk erramu-boneta, / Zeren nola baihaiz Parnason gainean / Bederatzi maiteki hazia, / heiek erakatsiz hik gur' adinean / Burutar' eman duk bertzek doi hasia. (514)

Oihenartek poeta izendatu zuen euskal egile bakarrak ez ote zuen laga arte poetikoan eredu moduan erakusteko neurtitzik? Iragan hurbilean halako goraipamena eskaini ondotik, erramu-boneta eman ondotik, ez du aintzakotzat hartzen arte poetikoan. Zergatik? Zalgizek poesia landu zuen berria Oihenarten hamalaurkun honen lekukotasunari esker soil-soilik heldu zaigunean, antzematerik ere ez dagoen arrazoiengatik arte poetikotik alboratuta ikusteak, Erregeren kontseilariaren langintza poetikoa galdua izatea are deitoragarriago bihurtzen du .

Berriro harira etorriz, bere ereduzko poesigintzari neurtitz zuzenen batzuk aurreratu zaizkiola aitortzen duen aldetik Oihenartek, honen prezeptibak xede duen berrikuntzak ez du baztertzen lehenaldi guztia, salbuespenik gabe. Garcia Galianorentzat Juan Boscanen Epistola a la Duquesa de Soma "puede considerarse como el manifiesto fundacional de la renovación literaria peninsular. Se atisba allí una actitud muy cercana a la, desde ámbito tan aparentemente distinto, sustentada por Oihenart en su Poética" (1993: 150). Ez dirudi Lasagabaster horraino iritsiko litzatekeenik. Adibidez, onartzen du Oihenartek euskal poetentzat eredu legez aurkezten duen Juan de Menak mintzaira poetikoa berritu zuela Behe Erdi Aroan, baina Oihenartek honengandik aukeratutako erakuskaria ez letorke lerro horretan kokatutako multzotik eta, azkenean, ondorioztatzen duenez,

\footnotetext{
No hay, al menos en los textos que conocemos, un replanteamiento mínimamente profundo del quehacer y de la materia poética, como lo hubo, por ejemplo, en la renovación poética iniciada por Boscán y consumada por Garcilaso en la poesía castellana del Renacimiento. (2003: 187)
}

Bere garaikideen ildoan lekutuz, eredugarritzat jotako ereduen antzera neurtitzak osatzea gomendatzen du Oihenartek. Eredu hauen tankeran jardutea aholkatzen dio euskal poetari, neurtitz zuzenak mamitu nahi izanez gero. Gakoa ez dago eredu horiek kopiatzean edo maileguan hartzean, horiek bezalatsu neurtitzak paratzean baino.

Sorkuntza artistikoaren euskarri imitazioa ezartzeaz harat, erretorikak elocutioaren ataletako batean ahoskera mailan aztertzen zituen baliabide batzuez egin beharreko erabilera zehaztera mugatu zela Oihenarten araugintza baieztatu da lehentxeago. Hala eta guztiz, elocutioaren beste alderdiren bat ere begietsi zuen, nahiz eta azalpenetan ez sartu.

Elocutioak berbaldi orok ontzat hartua izan zedin premiazko zituen ezaugarri edo dohainak zerrendatzen zituen. Lau bereizgarri zaintzea agintzen du: lehenik, garbitasuna edo zuzentasuna (puritas), bigarrenik, argitasuna edo gardentasuna (perspicuitas), hirugarrenik, apaindura (ornatus) eta, laugarrenik, egokitasuna edo decorum-a (aptum). Arau hauek baldintzarik gabe jarraitzekoak izan arren, laugarrenak, egokitasunari edo decorum-ari dagokionak, lehen hiruretan eragin dezake; izan ere, edukiak eta formak ez ezik, berbaldiak eta beronen komunikazio-testuinguru orokorrak, elkarri egokitzea derrigorrezko dute. Gaia, 
esakuntza, hartzailea... behar bezala bateratzekoak dira. Bestela esanda, nola testuak dioenak, testuaren erreferenteak, eta esateko erabilitako moduak, hala hauen maila pragmatikokomunikatiboak elkarri moldatzea nahitaezko dute. Ez bakarrik esana esateko erara, baita esakuntzaren baldintzetara eta igorleak eskuratu nahi dituen helburuetara ere egokitzea eskatzen du elocutioak. Egokitasun edo decorum-aren araua betetzeko, garbitasun edo zuzentasun, argitasun edo gardentasun eta apainduraren arauek, modulatu eta ñabartu egin beharko dute, komunikazioaren baldintzen arabera: nork hitz egiten duen, nori, non, noiz, zein asmorekin eta zeren gainean tasunak behatuz jokatzea nagusitzen da. Kanpo-egokitasuna berbaldi eta hizkuntzaz kanpoko zertzeladen harremanari dagokio.

Nire ustez, oso gaingiroki bada ere, arau hauek aipamenen bat izan zuten arte poetikoan eta estu-estu gorde zituen Oihenarten praxi poetikoak.

Adierazi denez, ia euskal bertsogile guztiak -Aita Haranbururen bertso batzuen salbuespenarekin- oker ibili dira. Horien artean daude Etxepare eta Ziburuko Etxeberri. Haatik, bada alderik batari eta besteari egotzitako akatsetan. Ziburuko Etxeberriren obran atzematen ez duen hutsa eransten dio Etxepareren idazlanari. Etxepareren zein Ziburuko Etxeberriren bertsogintzaren maila foniko-erritmikoko moldea arbuiatu zuen, baina, Ziburuko Etxeberriren obrari buruz, prosa alboratuz, poesia hobetsi izana deitoratu ondoren, honakoa gaineratu zuen:

Ie lui ay ouy dire au temps qu'il composoit ses Vers qu'il trauaillait principalement pour les mariniers Lesquers les chantoint sur la mer; Ce qui faict Iuger qu'il Escriuoit plus tost par Un motif de Charitté que par aucune ambition, ou Vainegloire, Et quil auoit le zèle de profiter à son prochain que doit avoir Un Veritable Ecclesiastique. (Lafitte, 1967: 39)

Anbizioak edo handinahiak gabe, karitateak bultzaturik ondu ditu bertsoak Ziburuko Etxeberrik. Elizgizon bati dagokion legez, lagun hurkoarentzat probetxuzkoa izatea bilatu du: marinelek itsasoan egiten dituzten egonaldi luzetan kanta zitzaten eta, hala, kristau-fedea eusten lagun ziezaien moldatu ditu.

Ziburuko Etxeberriren neurtitzek badute akatsik alderdi foniko-erritmikoetan, akatsok, ordea, nolabait "barkagarri" zaizkio edo zuritu dakizkioke elocutioaren laugarren araua zainduz, komunikazioaren baldintzen eskakizunen arabera jarduteagatik: nork, nori, non, noiz, zein asmorekin eta zeri buruz hitz egin zertzeladen agindupean aritu da. Ziburuko Etxeberri apaizak jende apalarentzat paratu zituen bertsoak, marinelentzat, itsasoan igarotzen zuten denboraldi luzetan elikagai izpirituala izan zezaten.

Ez da Etxepareren kasua. Oihenartek Etxepareren idazlanaren gainean eman epaiketan egokitasun edo decorum-aren araua urratzea leporatzen dio argi eta garbi. Honela aurkezten du arte poetikoak Etxepareren Linguae Vasconum Primitiae (1545):

Il est diuisé en deux parties, La premiere contient quelques fragments de La doctrine Chrestiene, Et lautre (outre les regrets de son Emprisonement) de Uers d'amour assés mal seans aUn Ecclesiastique, Et sur tout aUn curé ayant charge dames. (Lafitte, 1967: 37)

Oihenarten aburuz, Eiheralarreko bikarioari eliztarrei zuzentzea zegokion. Hori ere egin zuen desegokia ez den Linguae Vasconum Primitiaeren lehen partean, baina, bigarren parteko maitasunezkoetan ez zuen aintzakotzat hartu elocutioak galdatzen ziona. Ez zen esakuntzaren 
baldintzetara egokitu: egokitasunaren aginduarekin bat etortzeko, bere egoera zibiletik nor zuen hartzaile hausnartzeaz gain, estiloa gaiari moldatzeaz arduratu behar zuen. Jaramonik ere zien egin. Bere zeregina eliztarrak arteztea izanik, estilo apalean (genus humile) bideratutako gai erlijiosoa zuen idazketa-barruti. Bistakoa da arau horren berririk ez zuela Etxeparek eta baldin bazuen, alde batera utzi zuela, Linguae Vasconum Primitiaeko hitzaurrean adierazitako asmo-azalpenetatik ondoriozta daitekeenez: "eta baskoek, berzek bezala, duten bere lengoajian eskribuz zerbait doktrina, eta plazer hartzeko, solas egiteko, kantatzeko eta denbora iragaiteko materia" (79)3 izan zezaten idazten zuen. XVII. mendeko poetika batek nekez onartuko luke juntagailu kopulatiboak lotzen duena: doktrina eta plazer hartzea. Doktrinak estilo apala galdegiten zion, plazer hartzekoak, ostera, erdikoa. Jakinean edo jakin gabe Etxeparek ez du kontuan eduki irakastea helburu duen estilo apala, garapen txikia duen "ornatus"arekin batera, "puritas"ak eta "perspicuitas"ak ezaugarritzen dutela eta "ornatus"era gehiago jotzen duen erdi mailako estiloaz (genus medium) baliatzen dela plazeraren ingurukoa.

Irakaskuntza jomuga duten berbaldietarako estilo apala gomendatzen da. Zenbat eta zuzentasun eta argitasun handiagoa lortu, orduan eta eskuragarriago izango da xedea eta, horretarako, figura erretorikoak, batez ere tropoak, saihestea ondo datorkio. Apaindura erretorikoak, figura erretorikoen bidez, mintzairaren eguneroko erabileratik urrunduz, argitasunaren ezaugarria urratzeko joera du. Nolabait, iluntasunaren lizentzia legezkotzen du berbaldian. Figura erretorikoen bitartez ezustean harrapatuz hartzailea, honen gozamena bilatzea da apainduraren eginkizuna. Erdi mailako estiloak atsegin ematea (delectare) helburu izanik, maila neurritsuan bada ere, apaintzea eskatzen du.

Galdera ezinbestekoa da. Oihenartek, Etxeparek bezala, maitasunezko eta erlijiozko neurtitzak argitaratu zituen liburuxka berean. Oihenart prezeptistak ezarritako egokitasunaren araua hautsi ote zuen Oihenart poetak? Zortzi urte lehenago ezezaguna zuen arauren bat gehitzen ote du arte poetikoan? Nire ustez, ez.

Igorlearen esakuntzaren baldintzetara eta erdietsi gura dituen helburuetara egokitzea agintzen duela elocutioak esaten zen arestian. Egokitasuna gordetzeak zuzentasun, argitasun eta apainduraren arauetan ñabardurak galdatuko ditu idazlanaren igorle, hartzaile, asmo eta abarren baitan.

Oihenart ez da apaiza, ezkontzaz zaldun izatera iritsi den burgesa baino. Igorle honen estatusak ez du eragozten gaztaroan maitasunezko neurtitzak ontzea, ezta "je n'avais cherché que mon divertissement" (301) besterik begiratu ez izana ere. Olgeta jomuga zutenak jarraian datozen erlijiozkoengandik bereizten ditu. Azkenean erlijiozko neurtitz batzuk erantsi dituela badio, agidanez, argitaratu aurretxoan sortutakoak ditu. Dena dela, zeinahi denbora-tarteren aldea daukatela ere, giltza datza aldi desberdinetan paratutakotzat aurkeztean. Bestalde, batzuk eta besteak ez ditu lotzen "eta" juntagailuarekin. Guztiak eredu legez plazaratu izanak batzen ditu: maisu gisa eta ez poeta gisa agertzen du bere burua. Irakasteko jendarteratzen ditu. Irakasgaia gaian, edukian gabe, forman dago. Etxeparek euskara idazketara eta moldiztegira eramatea bazuen idazlana argitaratzeko arrazoi, Oihenartek bertso zuzenak egiten hezitzea. Buruen-buruenik gai berdinak landu zituzten biek: erlijioa eta maitasuna. Biek erlijioezkoetan

3. Erreferentzietan adierazitako ediziotik jasotako testu-aipamena eta orrialdea. 
doktrina erakutsi zuten eta maitasunezkoetan, batak, hartzaileranzko norabidea hobetsiz, honek plazer hartzea zuela xede adierazi zuen, besteak, igorlearen ikuspuntuan kokatuz, norbere olgeta bilatzea.

Beraz, Etxeparek atondu hitzaurrean, lehenbiziko euskal idazlea izateaz harro azaltzeaz gainera, euskara idatziz jartzeko jorratu dituen gaiekin daukan asmoa, esaten duenarekin eragin nahi duen efektura bideratzen duen bitartean, bestelakoa da Oihenarten aitorpena: esaten duenera gabe, esateko modura biltzen du arreta eta, aldi berean, esaten denak esateko modua baldintzatzen duela nabarmentzen. Bestela esan, Etxepareren helburua euskara idazketaren iragazitik iragaztea izanik eta, Oihenartena, berriz, euskaraz neurtitz zuzenak osatzeko eredua erakustea, biak bat egin zuten gai nagusietan, ez horrela, gaiok gobernatzeko moduan. Gaien arteko mugarriak finkatzen hasteko, ontze-garaiaren ikuspuntutik ezarritako banaketari, bere berezko uztatzat maitasunezkoak bakarrik hartzea gehitzen du Oihenartek.

Linguae Vasconum Primitiae izenburuarekin euskara idazketara jaio izana azpimarratzen zuen Etxepareren aurrean, Oten gaztaroa neurtitzetanekin, gaztaroan mamitutako neurtitzak soil soilik iragartzen ditu Oihenartek. Euskara idatzi izana batak, eta bere olgetarako moldatutako neurtitzak, besteak. Hitzaurrerako lagako dituzte gainontzeko xehetasunak. Xehetasun horien artean hartzailearengan eragin nahi duten efektua: Etxeparek "doktrina eta plazer hartzeko" eskaintzen dituen bitartean, Oihenartek elkarrengandik bereizi beharreko bi eredu ikusten ditu maitasuna ala erlijioa gai izan. Horregatik, hain juxtu, olgeta bilatuz paratuta zituen maitasunezkoei, besteak emendatzea nahitaezko zuen. Ez ote, gai bakoitzak eskakizun desberdinak dituela eta, ondorioz, bi eredu aurkezteko premia duela? Maitasunezkoetan erabilitako esateko moduak erlijiozkoetarako berdin-berdin balio bazuen, zertarako erantsi erlijiozkoak? Ez ote, batzuk eta besteak elocutioaren aldetik era desberdinean taxutzekoak izateak bi eredu zehaztera eraman zutela? Ez ote, Oihenartentzat "doktrina eta plazer hartzekoa" juntagailu kopulatiboaren lotura onartzen ez duten osagaiak direla? Alegia, doktrina irakasten duten neurtitzak eta plazer hartzeko ondutakoak juntagailu kopulatiboak uztarrezin izateak galarazten ziola maitasunezkoen moldea erlijiozkoetara hedatzea, eta, horrek, hain zuzen ere, derrigortu zutela bi eredu harilkatzera.

Oten gaztaroa neurtitzetan idazlanean, erlijiozko poesiei heldu aurretik musen arnasapean sortuz jardutea betiko baztertzen du (Toledo, 2009: 413-414). Inspirazioaren iturrian dagoen aldaketak badu islarik neurtitzetan. Esaterako, maitasunezkoetatik erlijiozkoetarako jauzian "ni" lirikoa desagertzen da. Idazlearen esku zegoen "ni" lirikoari eutsiz, maitasunean izandako barne-bizitza azaldu ostean, erlijioan duena adieraztea. Beste bat izan da, horratik, bere aukera: barne-bizitza erlijiosoa gabe, doktrina irakatsi: "Hamarkuna edo Jainkoaren hamar manuak", "Elizaren manuak", Eguberri-koplak", "Simeonen kanta", "Vexilla regis, etc.".

Maitasunezko neurtitzetako "ni" lirikoak, bere gizarte-klasearen gaineko zantzuren bat uzten zuen, zein geruzatan ez zen kokatzen adieraztean: "Hanbat beti / gotorreti / egiten derautazu, / baninz bezain / zenbait betzain / edo ilhagin zarpazu" diotsa Margaritari (II, 5; 312). Behe-mailakoa ez den maitemindu hau bere kexu, laudorio, ordain-eske eta abar kanporatzeko hizkera oso fina ekoizteko gauza da. Haatik, honen kultura jasoa eskuratzerik izan ez duten behizainek edo ilagin zarpailek ere osatzen dute Jainkoaren herria. Hauek ez dute gaitasunik maitemindu horren lantuak eta kontuak ulertzeko, ez esakunearen, ez esakuntzaren ikuspuntutik ere. Ezta premiarik ere, baina Jainkoaren herriaren parte diren aldetik erakutsi behar zaizkie Jainkoaren eta Elizaren aginduak. Elocutioa ezin izan daiteke berdina batean eta bestean. Irakurleari zuzendu zion aitzinsolasean doktrina-irakasle bihurtzearen egitekotik 
bere burua askatuz, beste batzuen zaletasuna eta trebetasuna akuilatzeko eredua ezartzera mugatu zela aitortu zuen. Ziburuko Etxeberriren gisakoei eredu bat eskaintzea du xede bakar, hots, ikasia den elizgizonari, eliztarrentzat poesia erlijiosoa paratzeko baliatu beharko lukeen modua agertu.

Nola erlijiozkoetan, hala bere olgetarako gaztaroan ondutako maitasunezkoetan ikasiak ditu gogoan Oihenartek. Neurtitzotan itxuratzen duen irakurle inplizitua, gutxienez, erdikoa edo erditik gora dagoen gizarte-klasekoa da: "ni" horren estatutu sozialak ez ezik, honen jarrera kortes, adeitsuak (Irastorza, 1992: 30), maite duen emakume bakoitza izendatzeko hautatutako izenaren mailak (Arkotxa, 1994: 434-439), erabiltzen duen hizkera jantziak... salatzen du. Olgeta soila zuen jomuga maitasunezkoak taxutzean: horra olgeta xede duen euskaldun ikasiarentzat eredua. Jarraian irakatsi nahi duen euskaldun ikasiarentzako eredua etorriko da. Horrela bada, argitaratutako bi ereduak bakoitzari egotzitako eginkizunak bereizten ditu: olgeta, irakatsi. Ez dira uztargarri bi helburuok, elocutio mailan eskakizun desberdinak dituztelako. Hala agintzen du erretorika prezeptistak.

Hitz batean, elocutioaren eremuan, metrikaren alorreko zuzenketa batzuekin, Ziburuko Etxeberri bezalakoak nahi ditu poesia erlijiosoan eta, profanoan, berriz, Oihenart bera bezalakoak. Bertso solte bakan batzuetatik harat euskal poeta bakar bat ere eredugarritzat aurkezten ez duelarik, ezin beste ondoriorik atera. Ereduak finkatzen lehena izatearen ohorea bereganatzeak galarazi ote zion Zalgize poeta arte poetikoko ereduen erresuman kokatzea? Baina, ohore hori hain preziatua bazen, zerk oztopatu zion prezeptibari behin betiko idazketa eman eta argitaratzea? Erantzun bila hasteak inolako oinarririk gabeko espekulazioetara baino eramaten ez duen arren, lehenago esan bada ezinak eragotzi ziezaiokeela lana amaitzea, zilegi bedi, beste bat gehitzeko lizentzia hartzea: eskatzen zuen ahaleginaren eta eskura zezakeen etekinaren arteko proportzio-falta.

Laburbilduz, Lapurdiko apaizarentzako gutunak honek egin galderari ihardesten dio: Oihenarten praxi poetikoaren euskarriak agertu. Arte poetikoaren zati nagusia neurtitzen aipamenek - bai imitatzeko diren ereduzkoenak, bai erdeinatzeko diren akastunenak - eta euskal poesiaren alderdi foniko-erritmikoen araugintzak betetzen badute ere, azken batez, argiago ala ilunago, gaingirokiago ala sakonago, erretorikak atal desberdinetan aztertzen zituen gorabeherei erantzuten die inventio, dispositio eta elocutioa arreta-mailaren baten jabe eginaz. Sail horietako bakoitzean azaleratutako ikuspegia bat dator garaikideek zutenarekin. Gertagarriena izanagatik, huts egindako saioa izatea deitoratu behar: zaila zuen, ezinezkoa ez esateagatik, fruitu-ekarle bilakatzea. Euskaldun ikasia hautatu zuen solaskide eta, jakin bazekien, hartzaile erreal gutxi erdietsiko zituela, poesiez lagun artean banatzeko argitalpena (Vinson, 1891: 100) baino asmo handiagokorik bideratu ez izanak berak iradoki dezakeen bezala. Halere, etsi gabe, poesia horien oinarri teorikoak azaltzeari ekin zion, nahiz eta behin betiko idazketarekin borobildu ez. Emankortasunik ezean, lekukotasun bat utzi zuen: hizkuntza ofizialak sendotuz eta, hauek sendotu ahala, ofizialak ez zirenak ahulduz zihoazen sasoian, garaiko poesigintza jantziaren agindupean moldatu zituen neurtitzak eta, gero, lantegi teorikoari heldu zionean zeregin praktikoan aritu zenean zertan zebilen ondo asko zekiela frogatu. Oihenart poeta eta Oihenart prezeptista harmonian daude. Lehenbizikoz, nola gaiak eta formak, hala hauen maila pragmatiko-komunikatiboak elkarri egokitzea nahitaezko dutela gauzatuta eta adierazita geratzen zen euskal praxi eta teoria poetikoan. 


\section{Erreferentziak}

Altuna, Patxi. 1981. Etxepare herri poeta. In Askoren Artean (arg.), Euskal Linguistika eta Literatura: Bide Berriak, 321-341. Bilbo: Deustuko Unibertsitatea.

Altuna, Patxi. 1994. Oihenarten euskal prosodia. In Askoren Artean (arg.), Oihenarten laugarren mendeurrena, 161-174. Bilbo: Euskaltzaindia.

Aristoteles. Poética. García Yebra, Valentin (arg.). 1974. Madrid: Editorial Gredos.

Arkotxa, Aurelia. 1994. Oihenarten amodiozko poesien azterketa konparatiboa. In Askoren Artean, Oihenarten laugarren mendeurrena, 401-450. Bilbo: Euskaltzaindia.

Chateaubriand, François René. 1951. Mémoires d’outre-tombe, I. Paris: Éditions Gallimard.

Dubois, Jacques, Francis Édeline, Jean-Marie Klinkenberg, Philippe Minguet, François Pire \& Hadeline Trinon. 1982. Rhétorique génerale. Paris: Éditions du Seuil.

Egiategi, Jusef. Lehen liburia edo filosofo huskaldunaren ekheia. 1983 [1785]. Peillen, Txomin (arg.). Bilbo: Euskaltzaindia.

Etxepare, Bernard. Linguae Vasconum Primitiae. 1995 [1545]. Kintana, Xabier (koor.). Bilbo: Euskaltzaindia.

Garcia Galiano, Ángel. 1993. El Arte Poética Vasca de Oihenart en su contexto humanista. Letras de Deusto, 60. 145-153.

Irastorza, Tere. 1992. Oihenarten Poemagintza. Hegats 7. 17-33.

Lasagabaster, Jesús María. 1986. El verso castellano modelo del verso vasco, en L’art poétique basque (1665), de Arnaud D’Oihenart. In Kossolf, A. David, Ruth H. Kossolf, Geoffrey Ribbans \& José Amor y Vázquez (coord.), Actas del VIII Congreso de la Asociación de Hispanistas: 22-27 agosto 1983, 113-122. Madrid: Ediciones Istmo.

Lasagabaster, Jesus Mª 2003. Razón y sinrazón de una renovación poética. En torno a l'art poétique basque, de A. D'Oihenart. In Arkotxa, Aurelia \& Lourdes Otaegi (arg.), Euskal Gramatikari eta Literaturari buruzko ikerketak XXI. mendearen atarian. 179-189. Bilbo: Euskaltzaindia.

Oihartzabal, Beñat. 1994. Oihenart, euskal gramatikarien aitzindaria. In Askoren Artean (arg.), Oihenarten laugarren mendeurrena, 27-47. Bilbo: Euskaltzaindia.

Oihenart, Arnauld d'. 1992 [1656]. Notitia utriusque Vasconiae. Edición facsímil. VitoriaGasteiz: Eusko Legebiltzarra. Estudio preliminar de Ricardo Cierbide, traducción del latín de Javier Gorosterratzu.

Oihenart, Arnauld d'. Euskal atsotitzak eta neurtitzak / Proverbes et poesies basques / Proverbios y poesías vascas. 2003 [1664?, 1657]. Patxi Altuna \& Jose Antonio Mujika (arg.). Bilbo: Euskaltzaindia.

Oihenart, Arnauld d'. 1967 [1665]. Lart poétique basque d'Arnaud d'Oyhénart (1665). Pierre Lafitte (arg.). Bayonne: Gure Herria.

Toledo, Ana. 2008. A propósito del prólogo del O.ten gaztaroa neurtitzetan. Sancho el Sabio 29. $135-155$.

Toledo, Ana. 2009. Linguae Vasconum Primitiae eta O.ten gaztaroa neurthitzetan: hain hurbil, hain urrun. In Askoren Artean (arg.), Juan Mari Lekuonari omenaldia, 403-427. Bilbo: Euskaltzaindia.

Vinson, Julien. 1891. Essai d’une Bibliographie de la Langue Basque. Paris: J. Maisonneuve. 